\title{
PERTAMBANGAN DAN DEFORESTASI: STUDI PERIZINAN TAMBANG BATUBARA DI PROVINSI KALIMANTAN TIMUR
}

\author{
Sonny ${ }^{*}$, Isal Wardhana \\ Dosen Fakultas Ekonomi Universitas Pamulang, Tangerang Selatan \\ ${ }^{*}$ email: sonny.majid@gmail.com
}

Paper Accepted: 21 Juni 2020

Paper Reviewed: 22-29 Juni 2020

Paper Edited: 01-17 Juli 2020

Paper Approved: 28 Juli 2020

\begin{abstract}
ABSTRAK
Penelitian ini mengurai pertambangan dan deforestasi dengan mengangkat studi perizinan tambang batubara khususnya di Provinsi Kalimantan Timur. Metode penelitian yang digunakan adalah pendekatan kualitatif, yakni suatu prosedur penelitian yang menghasilkan data deskriptif berupa kata-kata tertulis atau lisan dari orang-orang dan perilaku yang dapat diamati (Moelong, 2005: 4). Penelitian ini mengedepankan teori lensa atau teori perspektif (Sugiyono, 2012: 295). Metode ini digunakan, karena data yang dibutuhkan berupa sebaran informasi yang tidak perlu dikuantifikasikan. Jika mengacu pada judul penelitian yang dibahas, maka penelitian ini menggunakan studi kasus. Studi kasus adalah penelitian yang dilakukan secara intensif, terinci dan mendalam terhadap suatu organisasi, lembaga atau masyarakat mengenai gejala-gejala tertentu (Arikunto, 2002: 14). Sedangkan teknik pengumpulan datanya menggunakan metode studi literatur/dokumen. Data-data yang diperoleh selanjutnya diolah melalui reduksi dan menyajikan data dan selanjutnya menarik kesimpulan. Analisis data ini disebut sebagai mengolah dan menafsirkan data (Muhajir, 1996:104). Wilayah yang menjadi zona tambang batubara sebagaimana tercantum di dalam Rencana Pengembangan kawasan Peruntukkan Pertambangan Rencana Tata Ruang Wilayah Provinsi (RTRWP) Kalimantan Timur 20162036 masih ditemukan adanya tumpang tindih antara peruntukkan perkebunan dan pertambangan di hampir semua kabupaten/kota. Deforestasi tersebut berdampak kepada masyarakat lokal (masyarakat adat) sehingga masyarakat tidak bisa ikut serta dalam memberdayakan kawasan hutan dan juga menyebabkan terjadinya konflik horizontal maupun vertikal. Pemerintah Provinsi belum serius mengimplementasikan moratorium perizinan tambang yang seharusnya diterapkan dengan melihat daya dukung lingkungan. Untuk meminimalisir deforestasi ada baiknya konsisten dalam menerapkan kebijakan satu peta.
\end{abstract}

Kata Kunci: Deforestasi, Batubara, Kalimantan Timur

\section{PENDAHULUAN}

\section{Primadona Tambang Kalimantan Timur}

Provinsi Kalimantan Timur (Pemprovv Kaltim) sampai saat ini rupanya masih menjadi primadona sektor pertambangan, khususnya batubara. Menurut laporan Pemprov Kaltim melalui Dinas Penanaman Modal dan Pelayanan Terpadu Satu Pintu (DPMPSTP) setidaknya tercatat pada 2018 telah menerbitkan 2.527 izin usaha bidang penamaman modal dan sektoral yang tergolong jenis usaha primer, sekunder dan tersier. Dari 2.572 izin usaha tersebut tercatat 992 izin atau sebesar 39,26 persen merupakan subsektor pertambangan. Sisanya adalah subsektor perhubungan sebanyak 417 izin dan subsektor peternakan 317 izin.

Dalam Laporan Kajian Ekonomi dan Keuangan Regional Provinsi Kaltim Tahun 
2019 yang diterbitkan Bank Indonesia (BI) Perwakilan Kaltim menyebutkan lapangan usaha pertambangan dan galian triwulan IV 2018 tumbuh lebih tinggi dibandingkan periode sebelumnya yang 6,84 persen year on year (yoy). Menurut BI pertumbuhan tersebut merupakan tertinggi dalam enam tahun terakhir. Pangsa lapangan usaha pertambangan sebesar 46,73 persen, dengan persentasi ini maka memberikan andil sebesar 3,20 persen terhadap ekonomi Kaltim pada triwulan IV 2018.

Masih maraknya pertambangan batubara di Kaltim, juga di dorong oleh penambahkan kuota peningkatan batubara di provinsi tersebut oleh Kementerian Energi dan Sumber Daya Mineral (ESDM). Kementerian ESDM menyetujui penambahkan kuota pada produksi 32 perusahaan, dimana 18 perusahaan di antaranya punya site di Kaltim di semester II 2018 tepatnya pada September. Hal inilah yang membuat kegitan produksi terkonsentrasi pada triwulan IV 2018.

Menurut data IHS Energi periode Februari 2019 menarasikan produksi batubara di Kaltim pada triwulan IV 2018 mencapai 55,2 juta ton, mengalami kenaikan 9,06 persen (yoy). Kenaikan produksi tersebut disumbang oleh perusahaan PKP2B (Perjanjian Karya Pengusahaan Batubara). Dimana PKP2B pada triwulan IV 2018 tercatat sebesar 43,2 juta ton dan 88,9 juta ton pada semester II 2018.

Dari sisi ekspor volumenya pada triwulan IV 2018 ikut mengalami pertumbuhan sebesar 10,53 persen (yoy). Adapun peningkatan tertingginya yakni ekspor batubara ke Tiongkok yang pada triwulan IV 2018 tumbuh 26,79 persen (yoy). Peningkatan ekspor ini disebabkan rencana penutupan impor batubara akhir tahun 2018 yang menyebabkan para buyers mendorong impor pada bulan Oktober 2018. Masih menurut IHS Energy periode Februari 2019, penguatan juga terjadi akibat dukungan penjualan domestik (Domestic Market Obligation-DMO). Pada periode itu, Kaltim berhasil menjual 10,9 juta metrik ton batubara di pasar domestik, dengan pasokan tersebut maka tumbuh sebesar 19,75 persen (yoy). Di samping itu target produksi batubara nasional tahun 2019 sebesar 480 juta ton.

Maraknya perizinan tambang khususnya batubara di Kaltim juga didorong oleh kewenangan pemprov mengeluarkan penerbitan dan pencabutan izin tambang sebagaimana diatur di dalam Undang-Undang (UU) Nomor 23/2014 tentang Pemerintah Daerah. Dalam UU tersebut ada pasal yang menjelaskan tentang kewenangan gubernur untuk penerbitan dan pencabutan izin tambang.
Jaringan Advokasi Tambang (Jatam) melalui penjelasan resminya, menyebut bahwa selama ini masih terdapat perbedaan data tentang volume ekspor batubara. Ketidakselarasan terdapat pada data jumlah izin usaha pertambangan (IUP) di Provinsi Kaltim dengan data Kementerian ESDM. Contohnya data 2017 yang menyebutan jumlah IUP versi Pemprov ada 1.404 izin. Sementara data di Kementerian ESDM 1.194 izin. Dengan demikian ada selisih 210 IUP yang oleh Jatam dianggap bukan angka yang sedikit. Penelitian ini mengurai pertambangan dan deforestasi dengan mengangkat studi perizinan tambang batubara khususnya di Provinsi Kalimantan Timur.

\section{METODE PENELITIAN}

Metode penelitian yang digunakan adalah pendekatan kualitatif, yakni suatu prosedur penelitian yang menghasilkan data deskriptif berupa kata-kata tertulis atau lisan dari orangorang dan perilaku yang dapat diamati (Moelong, 2005: 4).

Penelitian ini mengedepankan teori lensa atau teori perspektif. Dimana teori ini membantu peneliti untuk membuat berbagai pertanyaan penelitian, memandu bagaimana mengumpulkan data dan analisis data (Sugiyono, 2012: 295). Metode ini digunakan, karena data yang dibutuhkan berupa sebaran informasi yang tidak perlu dikuantifikasikan. Jika mengacu pada judul penelitian yang dibahas, maka penelitian ini menggunakan studi kasus. Studi kasus adalah penelitian yang dilakukan secara intensif, terinci dan mendalam terhadap suatu organisasi, lembaga atau masyarakat mengenai gejala-gejala tertentu (Arikunto, 2002: 14).

Sedangkan teknik pengumpulan datanya menggunakan metode studi literatur/dokumen. Dokumen adalah peristiwa yang sudah berlalu. Dokumen bisa berupa/berbentuk tulisan, gambar atau karya-karya monumental dari seseorang (Sugiyono, 2012: 326). Data-data yang diperoleh selanjutnya diolah melalui reduksi dan menyajikan data dan selanjutnya menarik kesimpulan. Analisis data ini disebut sebagai mengolah dan menafsirkan data (Muhajir, 1996:104). 


\section{HASIL DAN PEMBAHASAN}

\section{Lubang Sisa Tambang dan Tumpang Tindih Perizinan}

Sektor pertambangan seperti pisau bermata dua. Di lain sisi menguntungkan, tetapi di sisi lainnya menjadi penyebab kerusakan ekologi dan deforestasi, selain pembukaan perkebunan skala besar. Wahana Lingkungan Hidup (Walhi) menyakatan bahwa praktik pertambangan menimbulkan daya rusak yang cukup besar, selain itu kerap merampas tanah-tanah rakyat. Belum lagi dampak yang ditimbulkan pascakegiatan, seperti kasus sejumlah anak di lubanglubang bekas galian tambang di Kaltim. Tercatat setidaknya sudah 27 anak meninggal dunia. Padahal sudah jelas-jelas ada kewajiban bagi para perusahaan tambang untuk adanya jaminan reklamasi, dana pasca-tambang dan menutup lubang-lubang bekas galian tambang.

Temuan Dinas Pertambangan Kaltim sampai Desember 2016 saja sudah ada 314 lubang bekas galian batubara yang dilakukan setidaknya 81 perusahaan tambang. Sampai dengan Agustus 2017 saja jumlah lubang bertambah menjadi 632 lubang yang didapati dari hasil pemotretan udara satelit Landsat. Terbanyak ada di Kabupaten Kutai Kartanegara ada 264 lubang, di Kota Samarinda 164 lubang, Kabupaten Kutai Timur 86 lubang, Kabupaten Paser 46 lubang, Kabupaten Kutai Barat 36 lubang, Kabupaten Berau 24 lubang dan Kabupaten Penajam Paser Utara satu lubang.

Konsorsium Pembaruan Agraria (KPA) pernah merilis data konflik lahan pada medio Januari-Juni 2012 mencapai 377.159 hektar dengan 25.000 kepala keluarga dengan 101 kasus di seluruh Indonesia. Sementara pada 2011 tercatat konflik lahan mencapai 472.084 hektar dengan 163 kasus. Perizinan yang tumpang tindih juga menjadi masalah. Kementerian ESDM saja pernah menemukan sekiranya 5.940 IUP bermasalah yang terdiri dari 3.988 IUP komoditas mineral dan 1.952 IUP komoditas batubara. Beberapa penyebab tumpang tindih lahan ini antara lain tentang beda komoditas, sampai dengan masalah batas wilayah yang dominan penentuannya masih manual.
Di Kaltim pada 2012 lalu saja sudah ada 33 kontrak PKP2B dan 1.386 IUP. Sampai dengan Mei 2012 sudah 1.419 izin dengan batas produksi batubara 220 juta ton. Jika mengacu pada jumlah tersebut maka diperkirakan jumlah tanah yang terkeruk bisa mencapai 2,6 miliar meter kubik. Greenpeace juga pernah merilis data di Provinsi Kalimantan Selatan dan Kalimantan Timur mereka mencatat hutan yang tersisa di dua wilayah tersebut hanya 400.000 hektare, dimana 320.000 hektare berada di wilayah konsesi batubara. Jika dibandingkan dengan data sebelumnya, sejak 2000 sudah 85.000 hektare hutan di Kalimantan Selatan dan 9.000 hektare hutan di Kalimantan Timur sudah hilang akibat konsesi batubara. Total tutupan hutan yang berada pada wilayah konsesi tambang untuk dua provinsi itu saja sudah mencapai 723.000 hektare atau 0,8 persen dari total wilayah hutan di Indonesia.

Salah satu penyebab deforestasi akibat kegiatan pertambahan khususnya batubara disebabkan lahirnya Undang-Undang No. 23 Tahun 2014 tentang Pemerintah Daerah yang disebutkan bahwa izin pertambangan diberikan kepada pemerintah daerah. Luas perizinan di Kaltim menembus 13,83 juta hektare, sebuah angka yang melewati luas provinsi Kalimantan Timur itu sendiri yang hanya 12,7 juta hektare.

Izin sektor pertambangan batubara menduduki posisi kedua penyebab deforestasi di Kalimantan Timur. Luas perizinan di seluruh Kalimantan Timur mencapai 5,137 juta hektare lebih yang terdiri dari dua konsesi, yakni IUP yang diterbitkan oleh walikota dan bupati pada masa lalu sebanyak 1.404 IUP dengan luas lahan 4,131 juta hektare lebih. Data 2019 disebutkan sisa IUP pasca-izin pertambangan diambil alih pemerintah provinsi tersisa 734 IUP.

Jenis izin pertambangan yang kedua tak lain perjanjian karya pengusahaan pertambangan batubara (PKP2B). Pemerintah pusat menerbitkan izin konsesi 30 PKP2B di Kalimantan Timur dengan total luas 1,006 juta hektare lebih. Data yang diperoleh peneliti, peruntukkan tambang dalam Rencana Pengembangan Kawasan Peruntukkan Pertambangan RTRWP Kalimantan Timur 2016-2036 adalah sebagai berikut: 
Tabel 1. Luas Pengembangan Kawasan Peruntukan Pertambangan

\begin{tabular}{|l|l|}
\hline \multicolumn{1}{|c|}{ Kabupaten/Kota } & \multicolumn{1}{|c|}{ Luas (Ha) } \\
\hline Balikpapan & $1,661.21$ \\
\hline Berau & $368,835.93$ \\
\hline Kutai Barat & $999,275.23$ \\
\hline Kutai Kartanegara & $1,114,406.46$ \\
\hline Kutai Timur & $1,669,734.19$ \\
\hline Mahakam Ulu & $554,675,34$ \\
\hline Paser & $276,888.49$ \\
\hline Penajam Paser Utara & $194,979.02$ \\
\hline Samarinda & $50,988.35$ \\
\hline Total & $\mathbf{5 , 2 3 1 , 4 4 4 . 2 1}$ \\
\hline
\end{tabular}

Sumber: Rencana Pengembangan Kawasan Peruntukkan Pertambangan RTRWP 2016-2036

Kalimantan Timur (diolah).

Dari tabel 1 di atas terlihat bahwa ada dua kabupaten di Kalimantan Timur yang paling luas peruntukannya sebagai Kawasan peruntukkan pertambangan, yakni Kabupaten Kutai Kartanegara seluas 1,114,406.46 hektare dan Kabupaten Kutai Timur dengan luas
1,669,734.19 hektare. Namun data di tabel tersebut kini masih menjalani proses registrasi CandC oleh pemprov Kalimantan Timur. Sementara itu untuk izin pertambangannya sebagai berikut:

Tabel 2. Luas Izin Pertambangan

\begin{tabular}{|l|l|}
\hline \multicolumn{1}{|c|}{ Kabupaten/Kota } & \multicolumn{1}{c|}{ Luas (Ha) } \\
\hline Balikpapan & $2,314.67$ \\
\hline Berau & $387,838.28$ \\
\hline Kutai Barat & $1,015,833.31$ \\
\hline Kutai Kartanegara & $883,054.39$ \\
\hline Kutai Timur & $1,487,966.47$ \\
\hline Mahakam Ulu & $508,413.13$ \\
\hline Paser & $233,201.05$ \\
\hline Penajam Paser Utara & $205,403.17$ \\
\hline Samarinda & $48,884.64$ \\
\hline Total & $\mathbf{4 , 7 7 2 , 9 0 9 . 1 0}$ \\
\hline
\end{tabular}

Sumber: diolah (2020)

684 | Sonny, et.al. Pertambangan dan Deforestasi: Studi Perizinan Tambang Batubara di Provinsi Kalimantan Timur 
Dari tabel 2, dapat dijelaskan bahwa luas izin pertambangan terdapat di dua kabupaten di yakni, Kabupaten Kutai Barat seluas 1,015,833.31 hektare dan Kabupaten Kutai Timur mencapai 1,487,966.47 hektare. Jumlah tersebut berbeda dengan tabel 1, dimana Kutai Kartanegara sebagai kabupaten terluas kedua dalam Rencana Pengembangan Kawasan Peruntukkan Pertambangan RTRWP Kalimantan Timur 2016-2036 yang justru pada luasan izin pertambangan kabupaten tersebut masuk pada posisi ketiga dengan 883,054.39 hektare

Tabel 3. Luas Izin Pertambangan di atas Desa

\begin{tabular}{|l|l|l|l|}
\hline \multicolumn{1}{|c|}{ Kabupaten/Kota } & \multicolumn{1}{|c|}{ Luas Desa (Ha) } & \multicolumn{1}{|c|}{ Puas Clip (Ha) } & \\
\hline Balikpapan & $33,913.24$ & $2,747.07$ & $8,10 \%$ \\
\hline Berau & $1,191,863.13$ & $384,571.73$ & $32,27 \%$ \\
\hline Kutai Barat & $1,307,324.32$ & $975,970.54$ & $74,65 \%$ \\
\hline Kutai Kartanegara & $1,887,401.86$ & $869,505.61$ & $46.07 \%$ \\
\hline Kutai Timur & $2,973,877.16$ & $1,450,264.18$ & $48.77 \%$ \\
\hline Mahakam Ulu & $1,014,247.02$ & $479,594.66$ & $47.29 \%$ \\
\hline Paser & $851,786.12$ & $242,019.78$ & $28.41 \%$ \\
\hline Penajam Paser Utara & $279,205.37$ & $195,740.84$ & $70.11 \%$ \\
\hline Samarinda & $66,413.88$ & $46,780.97$ & $70.44 \%$ \\
\hline Total & $\mathbf{9 , 6 0 6 , 0 3 2 . 8 0}$ & $\mathbf{4 , 6 4 7 , 1 9 5 . 3 9}$ & \\
\hline
\end{tabular}

Sumber: diolah (2020). Ket: Luas clip adalah; luas konsesi tambang yang dikomparasi dengan luas desa.

Dari tabel 3 setidaknya tergambar bahwa luas konsesi tambang yang dikomparasi dengan luas desa persentase tertingginya terdapat di Kabupaten Kutai Barat sebesar 74,65 persen dan di posisi kedua yakni Kota Samarinda 70,44 persen disusul Kabupaten Penajam Paser Utara 70,11 persen.

Tabel 4. Tumpang Tindih Izin Perkebunan dan Izin Pertambangan di atas Desa

\begin{tabular}{|l|l|l|l|}
\hline \multicolumn{1}{|c|}{ Kabupaten/Kota } & \multicolumn{1}{|c|}{ Luas Desa (Ha) } & \multicolumn{1}{c|}{$\begin{array}{c}\text { Luas Tumpang } \\
\text { Tindih (Ha) }\end{array}$} & \multicolumn{1}{|c|}{ Presentase } \\
\hline Berau & $323,859.71$ & $6,615.07$ & $2,4 \%$ \\
\hline Kutai Barat & $1,060,038.58$ & $214,427.32$ & $14 \%$ \\
\hline Kutai Kartanegara & $1,400,988.68$ & $196,127.02$ & $8,66 \%$ \\
\hline Kutai Timur & $2,186,339.79$ & $189,249.67$ & $5,44 \%$ \\
\hline Mahakam Ulu & $889,685.54$ & $48,360.49$ & $12,87 \%$ \\
\hline Paser & $348,954.96$ & $44,903.52$ & $18,18 \%$ \\
\hline Penajam Paser Utara & $180,238.14$ & $32,773.13$ & \\
\hline
\end{tabular}




\begin{tabular}{|l|l|l|l|}
\hline Samarinda & $24,461.18$ & $1,021.44$ & $4,18 \%$ \\
\hline Total & & $\mathbf{7 3 3 , 4 7 7 . 6 6}$ & \\
\hline
\end{tabular}

Sumber: diolah (2020).

Dari tabel 4, tergambar sangat jelas bahwa luasan kawasan yang tumpang tindih antara peruntukkan perkebunan dan pertambangan tertinggi ada di Kabupaten Kutai Barat sebesar 20,23 persen kemudian disusul Kabupaten Panajam Paser Utara 18,18 persen. Dimana keduanya merupakan salah bagian dari wilayah calon Ibukota Negara yang baru.

\section{Deforestasi}

Sampai dengan 2015, sebanyak 269 perusahaan yang mengantongi Hak Pengelolaan Kehutanan (HPH) dengan luas 19,6 juta hektare, kemudian ditambah lagi 280 perusahaan Hutan Tanaman Industri (HTI) menggarap 10,7 juta hektare (KLHK, 2015). Sedangkan sepanjang 2017 sudah 12,27 juta hektare dikelola 1.412 perusahaan perkembunan sawit (Dirjenbun, 2017) dan khusus pertambangan berupa IUP sudah 9.433 izin yang diberikan kepada perusahaan (PWYP, 2017).

Tumpang tindihnya perizinan antara banyak sektor kehutanan dan pertambangan, menyebabkan terjadinya ketimpangan penguasaan, masalah buruknya pengelolaan kehutanan. Paling tidak ada 14,7 hektare terjadi tumpang tindih perizinan. Pada kurun waktu 2013-2016 saja tingkat deforestasi mencapai 1,8 juta hektare. Jumlah tersebut tersebar di delapan provinsi. Namun dari delapan provinsi tersebut, Kalimantan Timur menjadi wilayah tertinggi perubahan tutupan hutan dengan luas sekitar 472.000 hektare.

Akibat tumpang tindih perizinan tersebut, pada rentang waktu yang sama, lebih dari 50.000 hektare hutan alam hilang. Tersisa 424.000 hektare atau 29 persen hutan alam dari area yang terjadi tumpang tindih. Lagi-lagi di Provinsi Kalimantan Timur yang merupakan wilayah dengan kasus tumpang tindih perizinan antara perkebunan dengan pertambangan.

Provinsi Kalimantan Timur sejak 20132016 telah menyumbang deforestasi 144.000 hektare. Salah satu penyebabnya tak lain aktivitas pertambangan, khususnya pertambangan batubara. Pertambangan batubara tersebut menjadi salah satu penyebab hilangnya hutan alam di provinsi berjuluk "Borneo."

Perubahan pola penutupan lahan pada areal izin pinjam pakai kawasan hutan untuk pertambangan batubara, terus menunjukkan adanya kecenderungan peningkatan luas, khususnya untuk areal bukan hutan dan penurunan luas untuk areal hutan. Deforestasi bersih yang terjadi di areal izin sebesar 1.566,83 hektare atau 3,26 persen dari luas total areal izin pinjam pakai kawasan hutan untuk pertambangan batubara khususnya di Kabupaten Kutai Kartanegara. Selama kurun waktu tujuh tahun (2010 s/d 2016), laju deforestasi yang terjadi sebesar 223,83 hektare per tahun atau 0,46 persen dari luas areal izin pertambangan di dalam kawasan hutan.

Sementara di Kabupaten Paser, laju deforestasi sepanjang 2000 - 2013 saja dominan disumbang dari kegiatan-kegiatan perizinan bidang kehutanan dan perkebunan sebanyak 53 izin dengan luas 856.210,64 hektare. Untuk degradasi hutan dan lahan dipicu oleh kegiatan pertambangan sebanyak 86 izin dengan luas 123.200,195 hektare. Dari perizinan tersebut, setidaknya menghasilkan lahan kritis 640.253 hektare atau 56 persen dari luasan Kabupaten Paser. Selain itu tumpang tindih perizinan kehutanan, perkebunan dan pertambangan masih terjadi. Kondisi tersebut akhirnya berdampak pada masalah hak kelola hutan oleh masyarakat yang kerap tidak diakui oleh pemerintah daerah Kabupaten Paser. Termasuk perbaikan masalah lingkungan hidup, belum menjadi prioritas utama perusahaan-perusahaan yang beroperasi di sektor perkebunan dan pertambangan.

Masalah lain yang menjadi penyebab deforestasi selain tumpang tindih perizinan antar-sektor tadi (perkebunan dan pertambangan), tak lain munculnya kebijakan moratorium pada wilayah penundaan pemberian izin baru tentang hutan alam dan lahan gambut. Kebijakan moratorium tersebut dituangkan melalui Inpres No. 6 tahun 2017 yang merupakan keberlanjutan dari kebijakan moratorium sebelumnya yang tercantum di dalam Inpres No. 10 Tahun 2011. Kedua aturan ini merupakan bukti adanya pepanjangan penundaan sementara (moratorium) izin hutan dan lahan yang sudah berjalan enam tahun dengan perpanjangan setiap dua tahun.

Tumpang tindih tersebut menjadi pemicu konflik sosial mengenai pengelolaan sumber daya alam. Konflik horizontal dan konflik vertikal hingga kini masih terjadi. UndangUndang Kehutanan 2019 yang menegaskan 
tentang hutan negara, membuat masyarakat adat - lokal menjadi terbatas dalam hal mengakses sumber daya alam yang sebenarnya berada dalam wilayah adatnya.

Konflik sosial (horizontal maupun vertikal) hingga 2017 terus mengalami tren kenaikan. Pada 2013 sudah 161 konflik, bertambah di tahun 2017 menjadi 1.084 kasus. Kasus konflik tersebut di dominasi konflik vertikal (antara masyarakat dengan perusahaan). Kenapa dominan konflik vertikal, hal ini disebabkan karena semakin marak perusahaan yang berekspansi di sektor perkebunan dan pertambangan.

Konflik pada sektor pertambangan juga dipicu jauh-jauh hari setelah diterbitkannya Peraturan Pemerintah No. 2 Tahun 2008 tentang Tambang di Kawasan Hutan Lindung. Di dalam peraturan pemerintah tersebut mengatur tentang jenis dan tarif atau jenis penerimaan negara bukan pajak, yang sudah barang tentu berasal dari penggunaan Kawasan hutan untuk pembangunan di luar kegiatan kehutanan. Peraturan pemerintah ini dianggap menjadi penyebab perubahan fungsi kawasan hutan lindung menjadi Kawasan pertambangan yang jika di kira-kira luasnya bisa mencapai 2.751.702 hektare.

Wahana Lingkungan Hidup (Walhi) pernah mensinyalir, kegiatan pertambangan di dalam hutan lindung adalah bagian dari skenario Badan Bisnis Dunia untuk Pembangunan Berkelanjutan (WBCSD) yang merupakan konsorsium 120 perusahaan dunia yang pernah menginisiasi Mining Mineral and Sustainable Development (MMSD). Skenario ini melibatkan Dewan Internasional untuk Mineral, Logam dan Lingkungan (ICME) yang berkedudukan di Ottawa dengan beranggotakan perusahaanperusahaan tambang dunia. Kedua lembaga tersebut (WBCSD dan ICME) mendesak Badan Konservasi Dunia (IUCN) agar meloloskan skema pemanfaatan hutan lindung dengan kegiatan eksploitasi tambang.

Konsep penyelamatan yang pernah dilakukan seperti Forest Law Enforcement Governance (FLEG) dan Forest Law Enforcement Governance and Trade (FLEGT) bahkan yang terakhir dengan skenario Reduction Emmision for Deforestation and Degradation (REDD) ternyata sampai sekarang tidak terlalu memberikan pengaruh dalam upaya menekan deforestasi. Deforestasi yang diakibatkan oleh aktivitas pertambangan ikut mencemari sungai-sungai. Jumlah daerah aliran sungai (DAS) yang rusak sebanyak 4000 DAS, dimana 108 di antaranya sudah tercemar.

\section{Kebijakan Tata Ruang selalu Menjadi Pemicu Konflik}

Konsep kebijakan dalam persoalan tata ruang dalam praktiknya selalu memicu kekisruhan (konflik). Kondisi ini disebabkan lantaran buruknya nalar politik pemerintah dalam melihat kebutuhan masyarakat. Setiap wilayah di Indonesia selalu dilihatnya sebagai material, menyebabkan kerangka berfikir yang dipakai tak lepas dari domain kapitalisme atau politik "pasar bebas." Domain itu pada akhirnya menggiring setiap kebijakan ruang-ruang yang ada sebagai medium investasi. Masih jarang kebijakan yang dibuat, baik di pemerintah daerah bersikap mengedepankan kepentingan (kebutuhan) masyarakat. Lebih dari bagaimana cara mendongkrak uang negara.

Era otonomi daerah (desentralisasi) yang diharapkan mengubah mindset dalam membuat kebijakan, sepertinya juga belum banyak memberikan perubahan. Kebijakan yang dirancang masih di dominasi menggunakan pendekatan top down, bias sectoral, bias negara dan berpihak pada pemodal. Kita bisa ambil contoh gagasan Kawasan Kelola Rakyat (KKR) yang dimaksudkan untuk mengimbangi desakan mindset kapitalistik tadi. Dimana tujuannya adalah menyelamatkan masyarakat dalam pengelolaan lingkungan, khususnya masyarakat adat sehingga hak-haknya terpenuhi. KKR sendiri merupakan gagasan yang dibuat menggunakan sudut pandang penghormatan kebudayaan. Misalnya konsep keruangan "bentang alam kebudayaan." Henry Levebre dalam "La Production de Lescape" menjelaskan bahwa sebuah ruang diproduksi dalam dialektika antara manusia dan hamparan laut, darat, udara tempat ia hidup dan mati.

Peraturan Pemerintah No. 6 Tahun 2007 yang diubah menjadi Peraturan Pemerintah No. 3 Tahun 2008 tentang Tata Hutan dan Penyusunan Rencana Pengelolaan Hutan serta Pemanfaatan Hutan tidak memberi banyak ruang kepada masyarakat yang hidup di sekitar kawasan hutan. Mereka hanya dibolehkan menempati ataupun menggunakan untuk berladang pada tempat yang telah ditentukan, dan harus mengantongi izin setiap menggunakan kawasan itu.

Undang-Undang No. 41 Tahun 1999 tentang Kehutanan menyebutkan, hutan negara yang berada dalam wilayah masyarakat hukum adat. Hal ini jelas menekankan, bahwa hutan adat adalah Kawasan yang dikuasai negara. Bila mengacu konsepsi "hak menguasai negara" maka bisa ditafsirkan bahwa hutan negara bukan di bawah kontrol penuh kelompok 
masyarakat yang ada di dalamnya. Karena terdapat sejumlah prosedur yang kemudian bisa ditetapkan menjadi hutan adat. Undang-Undang Kehutanan juga menyebutkan, penguasaan hutan oleh negara tetap memperhatikan hak masyarakat adat, sepanjang kenyataannya masih ada dan diakui keberadaannya, serta tidak bertentangan dengan kepentingan nasional.

Ini artinya, keberadaan masyarakat adat yang sesungguhnya sudah ada sebelum undangundang tersebut lahir, harus menunggu proses selanjutnya untuk dapat diakui sebagai komunitas adat. Pendapat ini bisa semakin kuat dengan mekanismen pinjam pakai kawasan hutan dan aturannya sebelumya yang membolehkan penambangan di kawasan hutan lindung. Keberadaan masyarakat adat di Indonesia belum diakui secara formal, meskipun dunia internasional sebenarnya sudah mengakuinya. Peraturan yang dibuat oleh pemerintah (daerah) selalu kalah dengan kepentingan ekonomi. Sehingga keberadaan masyarakat adat tidak dilibatkan langsung dalam pemanfaatan dan pengelolaan hutan.

Jika dibandingkan dengan konsep hutan lindung yang diatur di dalam Undang-Undang Kehutanan dimana hutan lindung adalah kawasan hutan yang memiliki fungsi pokok sebagai perlindungan sistem penyangga kehidupan untuk mengatur tatar air, mencegah banjir, mengendalikan erosi, mencegah instruisi air laut dan memelihara kesuburan tanah, sebenarnya sudah banyak dipraktikkan pada masyarakat adat pada pengelolaan hutan adat. Hanya beda pada tataran praktik dan orientasi pengelolaannya. Hutan adat berorientasi untuk keberlangsungan hutan yang diwariskan kepada generasi selanjutnya, sedangkan hutan lindung lebih beriorientasi pada keseimbangan ekologi yang disisipi ekstraksi hutan tanpa memberikan dampak langsung kepada masyarakat sekitar.

Pemerintah Daerah Provinsi Kalimantan Timur dalam menerbitkan peraturan belum melakukan penyesuaian-penyesuaian dengan prinsip perlindungan hutan. Hal ini bisa dilihat dari belum adanya kewajiban penambang sejak perencanaan, pelaksanaan maupun reklamasi. Hasilnya kerusakan hutan pun tidak dapat dihindari oleh karena aturan yang dibuat Pemerintah Daerah Kalimantan Timur hanya memuat pengecualian kewajiban reklamasi, termasuk terbitnya keputusan yang tidak mendukung kegiatan reklamasi bekas galian pertambangan batubara.

Praktik peraturan mengenai reklamasi tambang batubara di area hutan Kalimantan Timur tidaklah baik. Ini juga disebabkan pilihan-pilihan kewajiban reklamasi yang berkonsekuensi hilangnya hutan. Pemerindah Daerah Kalimantan Timur dinilai tidak berupaya memperbaiki lemahnya pengawasan terhadap perusahaan pertambangan batubara. Praktik reklamasi sebagaimana yang diwajiban kepada perusahaan pertambangan batubara tidak dijalankan. Dan ini hampir semua terjadi di seluruh kabupaten/kota yang memiliki area pertambangan batubara khususnya yang berada di kawasan hutan.

Jumlah IUP yang dikeluarkan oleh para kepala daerah (khususnya bupati dan walikota) di Provinsi Kalimantan Timur sebenarnya sudah terlalu banyak, tanpa memperhatikan kemampuan (daya dukung) lingkungan sehingga memicu bahaya. Disini sangat terlihat Pemerintah Daerah Provinsi Kalimantan Timur belum serius memberlakukan kebijakan moratorium perizinan tambang. Padahal kekarut-marutan proses pengeluaran izin tambang kerapkali menimbulkan konflik di lapangan.

Program pemutihan yang diterapkan pemerintah terhadap IUP yang beroperasi di kawasan hutan secara non prosedural belum direspon positif bahkan para pemegang IUP juga tidak aktif, hal ini dikarenakan jangka waktu pemulihan yang diberikan dinilai terlalu singkat. Dualisme - tumpang tindih perizinan usaha tambang di kawasan hutan tetap dianggap menjadi alasan terjadinya konflik.

Terkadang dualisme itu terjadi antara Kementerian Energi dan Sumber Daya Mineral dan Kementerian Lingkungan Hidup dan Kehutanan. Semestinya pemerintah bisa mencoba dengan menerapkan tata kelola perizinan tambang yang transparan dan akuntabel, sehingga tercipta harmonisasi regulasi, pengawasan, pengendalian, penegakkan hukum. Dan yang tak kalah penting bila perlu dibuatkan kebijakan satu peta.

\section{KESIMPULAN}

Dari uraian di atas ada beberapa poin sebagai kesimpulan yang dianggap menjadi penyebab deforestasi di Provinsi Kalimantan Timur; pertama, wilayah yang menjadi zona tambang batubara sebagaimana tercantum di dalam Rencana Pengembangan kawasan Peruntukkan Pertambangan Rencana Tata Ruang Wilayah Provinsi (RTRWP) Kalimantan Timur 2016-2036 masih ditemukan adanya tumpang tindih antara peruntukkan perkebunan dan pertambangan di hampir semua kabupaten/kota. Kedua, deforestasi tersebut berdampak kepada masyarakat lokal 
(masyarakat adat) sehingga masyarakat tidak bisa ikut serta dalam memberdayakan kawasan hutan dan juga menyebabkan terjadinya konflik horizontal maupun vertikal.

Ketiga, Pemerintah Provinsi belum serius mengimplementasikan moratorium perizinan tambang yang seharusnya diterapkan dengan melihat daya dukung lingkungan. Keempat, untuk meminimalisir deforestasi ada baiknya konsisten dalam menerapkan kebijakan satu peta.

\section{DAFTAR PUSTAKA}

Arikunto, Suharsimi. (2002). Prosedur Penelitian: Suatu Pendekatan Praktek. Jakarta: Rhinkha Cipta.

Bank Indonesia Perwakilan Kaltim. (2019). Laporan Kajian Ekonomi dan Keuangan Regional Provinsi Kalimantan Timur, hal. 5 .

(2019). Laporan Kajian

Ekonomi dan Keuangan Regional Provinsi Kalimantan Timur, hal. 6.

(2019). Laporan Kajian

Ekonomi dan Keuangan Regional Provinsi Kalimantan Timur, hal. 7.

(2019). Laporan Kajian

Ekonomi dan Keuangan Regional Provinsi Kalimantan Timur, hal. 8.

Eddy Mangopo Angi, Catur Budi Wiati. (2017). Kajian Ekonomi Politik Deforestasi dan Degradasi Hutan dan Lahan di Kabupaten Paser, Kalimantan Timur. Jurnal Penelitian Ekosistem Dipterokarpa, Vol. 3, No. 2, hal. 76 .

FWI. (2017). Executive Summary, Silang Sengkarut Pengelolaan Hutan dan Lahan di Indonesia. Studi Kasus di 9 provinsi di Indonesia; Aceh, Kalimantan Barat, Kalimantan Timur, Kalimantan Utara, Riau, Sulawesi Tengah, Sulawesi Barat, Sumatera Selatan, hal 2-9; https://fwi.or.id/wp-

content/uploads/2017/12/executivesummar y8des17_final.pdf

Muhajir, Noeng. (1996). Metodologi Penelitian Kualitatif. Yogyakarta: Rake Sarasin.

Muhdar, Muhammad. (2015). Aspek Hukum Reklamasi Pertambangan Batubara pada Kawasan Hutan di Kalimantan Timur. Jurnal Mimbar Hukum, Vol. 27, No. 3, hal. 485

Moelong. Lexy J. (2005). Metodologi Penelitian Kualitatif. cet. ke-11. Edisi Revisi. Bandung: Rosdakarya.
Pemprov Kaltim (2020). Rencana Pengembangan Kawasan Peruntukkan Pertambangan RTRWP 2016-2036 Kalimantan Timur.

Retna Kartikasari, Arief Rachmansyah, Amin Setyo Leksono. (2018). Dampak Pertambangan Batubara terhadap Laju Deforestasi di Kabupaten Kutai Kartanegara Provinsi Kalimantan Timur. Indonesian Green Technology Journal, hal. 18.

Ridwan. (2004). Statiska untuk Lembaga dan Instansi Pemerintahan-Swasta. Bandung: Alfabeta.

Subarudi, Hariadi Kartodiharjo, Sudarsono Soedomo, Hadiyanto Sapardi. (2016). Kebijakan Resolusi Konflik Tambang Batubara di Kawasan Hutan di Kalimantan Timur. Jurnal Analisis Kebijakan Vol. 13, No. 1, hal. 68-69.

SJA, Ahmad, Jidan (2013). Pemetaan Partisipatif dan Peneguhan Kembali Keyakinan Hak-hak Masyarakat Muluy untuk Mengelola Hutan Adat dan Menolak Kawasan Lindung, Balikpapan, Yayasan Padi Indonesia.

Sugiyono. (2012). Metode Penelitian Kuantitatif, Kualitatif, dan Kombinasi (Mixed Methods). Alfabeta, Bandung, hal. 290.

. (2012). Metode Penelitian Kuantitatif, Kualitatif, dan Kombinasi (Mixed Methods). Alfabeta, Bandung, hal. 295.

. (2012). Metode Penelitian Kuantitatif, Kualitatif dan Kombinasi (Mixed Methods). Alfabeta. Bandung. hal. 308.

. (2012). Metode Penelitian Kuantitatif,

Kualitatif dan Kombinasi (Mixed Methods). Alfabeta. Bandung. hal. 309.

. (2012). Metode Penelitian Kuantitatif,

Kualitatif dan Kombinasi (Mixed Methods). Alfabeta. Bandung. hal. 316. (2012). Metode Penelitian Kuantitatif, Kualitatif dan Kombinasi (Mixed Methods). Alfabeta. Bandung. hal. 326.

Walhi Kaltim. (2013). Borneo Outlook 2013. Ed. executive report, Samarinda.

Internet:

Antara.

https://kaltim.antaranews.com/berita/5340 5/selama-2018-pemprov-kaltim-terbitkan2527-izin-usaha, diakses 29/5/2019.

Bisnis Indonesia. (2019) https://kalimantan.bisnis.com/read/201902 28/408/894646/sinkronisasikan-izinusaha-tambang-pemprov-kaltim-gelarsidak, diakses 29/5/2019 
https://kalimantan.bisnis.com/read/201812 16/408/870133/2018-kaltim-terbitkan-925izin-usaha-sektor-pertambangan, diakses 29/5/2019.

CNN Indonesia. (2019). https://www.cnnindonesia.com/ekonomi/20 190902095809-92-426714/perusahaanraksasa-batu-bara-di-bumi-kaltim-ibukota-baru, diakses 24/11/2020

JATAM. https://www.jatam.org/2019/03/08/siapapenguasa-tanah-kaltim/, diakses Rabu $(29 / 5 / 2019)$

KPA.

https://www.kpa.or.id/news/blog/hari-antitambang-bikin-banyak-masalahindonesia-mesti-tinggalkan-industripertambangan/, diakses, 30/5/2019.

Rahmi, Ika Prida. (2020) https://kaltimkece.id/warta/lingkungan/det ail-perizinan-kaltim-yang-lebih-luas-daridaratan-provinsi-dan-membuat-murkapimpinan-kpk, diakses 25/11/2020

Yovanda, Mongabay.

(2019)

https://www.mongabay.co.id/2019/10/26/l ubang-tambang-batubara-di-kalimantantimur-begini-rencana-pemulihannyal, diakses 24/11/2020. 